\title{
CHARACTERIZATION OF URINARY BIOACTIVE PHENOLIC METABOLITES EXCRETED AFTER CONSUMPTION OF A CUP OF MOUNTAIN TEA (Sideritis scardica) USING LIQUID CHROMATOGRAPHY - TANDEM MASS SPECTROMETRY
}

\author{
Jasmina Petreska Stanoeva, Daniela Bagashovska, Marina Stefova* \\ Institute of Chemistry, Faculty of Natural Sciences and Mathematics, \\ Ss. Cyril and Methodius University, Arhimedova 5, 1000 Skopje, \\ Republic of Macedonia \\ marinaiv@pmf.ukim.mk
}

\begin{abstract}
A nutrition experiment was performed for studying the bioavailability of polyphenols from Sideritis scardica with healthy human subjects, who consumed a standardized $S$. scardica decoction after which urine was collected and analyzed. Thirty five polyphenolic compounds in the ingested decoction and sixty three of their metabolites in urine collected after ingestion were identified using HPLC/MS ${ }^{n}$. It was shown that phenolic compounds present in the $S$. scardica decoction are extensively conjugated to glucuronides, sulfates and also transformed to methylated forms after oral administration. Thirty one different metabolites of hypolaetin, methylhypolaetin, isoscutellarein, methylisoscutellarein and apigenin, and 32 phenolic acids metabolites were detected in the analyzed urine samples, whereas hypolaetin and isoscutellarein metabolites were the most abundant. This enabled polyphenols metabolites patterns to be obtained, which is a crucial step towards revealing the bioavailability and metabolism of phenolic compounds from $S$. scardica in human. The identification and structure elucidation of these metabolites provided essential data for further studies of $S$. scardica polyphenols bioavailability.
\end{abstract}

Key words: Sideritis scardica; mountain tea; flavonoids; polyphenols; metabolites; bioavailability

\section{КАРАКТЕРИЗАЦИЈА НА БИОАКТИВНИ ФЕНОЛНИ МЕТАБОЛИТИ ВО УРИНА ПО КОНСУМИРАњЕ НА ПЛАНИНСКИ ЧАЈ (Sideritis scardica) СО ПРИМЕНА НА ТЕЧНА ХРОМАТОГРАФИЈА СО ТАНДЕМ МАСЕНА СПЕКТРОМЕТРИЈА}

За проучување на биорасположливоста на полифенолите од Sideritis scardica изведен е експеримент со здрави доброволци кои консумираа стандардизирана чајна напивка (декокт) од S. scardica, по што беше собирана и анализирана нивната урина. Со употреба на HPLC/ $\mathrm{MS}^{n}$ во урината собрана по внесувањето на декоктот во организмот се идентификувани триесет и пет полифенолни соединенија и шеесет и три нивни метаболити. Покажано е дека фенолните соединенија присутни во декоктот од S. scardica по ингестијата во голема мера се конјугирани и се наоѓаат во облик на глукурониди и сулфати, а исто така се трансформирани и во метилирани форми. Во анализираните примероци урина е утврдено присуството на триесет и еден различен метаболит на хиполетин, метилхиполетин, изоскутелареин, метилизоскутелареин и апигенин, од кои најзастапени се метаболитите на хиполетин и изоскутелареин. Ова овозможува да се добие профилот на полифенолните метаболити, што е клучниот чекор во откривањето на биорасположливоста и метаболизмот на фенолните соединенија од $S$. scardica во човечкиот организам. Со идентификацијата и утврдувањето на структурата на овие метаболити се добиваат неопходни податоци за понатамошните студии на биорасположливоста на полифенолите од S. scardica.

Клучни зборови: Sideritis scardica; планински чај; флавоноиди; полифеноли; метаболити; биорасположливост 


\section{INTRODUCTION}

In the Balkan countries, the dried inflorescences of number of species of genus Sideritis L. (Lamiaceae) are used to prepare traditional beverage so-called mountain tea. In R. Macedonia these species are called "sharplaninsкi chaj" or "planinski chaj" and are widely used as a refreshing herbal tea as well in the folk medicine for treatment of cough, bronchitis, asthma and curing gastrointestinal disorders. This type of drink is usually obtained for domestic use and consumption.

Pharmacological studies indicate that Sideritis samples have various bioactivities as anti-ulcer, anti-inflammatory and antioxidant activity [1]. Regarding the chemical constituents of Sideiritis species, more than 50 compounds have been isolated and identified up to now, such as flavone aglycones and glycosides [2-7], diterpenes [8] and phenylethanoid glycosides $[6,7,9]$.

Although many investigations have been conducted in the fields of pharmacology and phytochemistry of Sideritis, the fate of its effective constituents after oral administration of the decoction in the human body is still not elucidated. The limited knowledge about the metabolism of Sideritis decoction restricts the thorougher pharmacological and clinical studies of the bioactive constituents of Sideritis.

There are a number of reports on the bioavailability of flavonoids in humans as well as on the biological activity of flavonoids in human clinical and intervention studies [10]. It is now clear that flavonoids are absorbed into the plasma and mostly are present in the blood and urine as conjugates, but the extent of absorption, bioavailability and biological activity is dependent on their nature. The use of in vitro studies and animal models has provided useful information on the bioavailability and has implied the small intestine as the site for their absorption. Since flavonoids exert biological effects in vivo in human intervention studies, one hypothesis to explain their efficacy and bioavailability is that flavonoid conjugates, i.e. metabolites retain some of the biologically active properties.

In our previous study, chemical characterization of Sideritis scardica and Sideritis raeseri decoction has been successfully performed using HPLC/DAD/ESI/MS ${ }^{n}$ and 35 major polyphenolic constituents were identified $[6,7,11,12]$. In the present study, identification of these compounds and their conjugated forms in human urine after ingestion of $S$. scardica decoction was carried out. Urine samples were collected over a $24 \mathrm{~h}$ period postingestion of the decoction and analyzed, without prior hydrolysis, by HPLC/DAD/MS ${ }^{n}$. This enabled polyphenols metabolites patterns to be obtained consisting of the individual flavonoid glucuronide and sulfate metabolites together with phenolic acids metabolites that appeared in urine after supplementation, which is a crucial step towards revealing the bioavailability and metabolism of phenolic compounds from $S$. scardica in human.

\section{EXPERIMENTAL}

\subsection{Reagents and standards}

Formic acid, methanol and water, all of analyFormic acid, methanol and water, all of analytical grade were purchased from Merck KGaA (Darmstadt, Germany). Authentic samples of verbascoside, forsythoside B, leucoseptoside A, hypolaetin 7-O-[6"'-O-acetyl]allosyl $(1 \rightarrow 2)$-glucoside, isoscutellarein 7O-[6"'-O-acetyl]-allosyl $(1 \rightarrow 2)$ glucoside, hypolaetin $7-O-\left[6^{\prime \prime \prime}-O\right.$-acetyl]-allosyl $(1 \rightarrow 2)$ glucoside, 3'-O-methylhypolaetin 7-O-[6"''-O-acetyl]-allosyl- $(1 \rightarrow 2)$ glucoside, 4 '- $O$-methylhypolaetin 7-O-[6"'-O-acetyl]-allosyl $(1 \rightarrow 2)$ glucoside, apigenin 7-(6"-p-coumaroylglucoside), isoscutellarein 7-O-[6"'-O-acetyl]-allosyl- $(1 \rightarrow 2)$ [6"-O-acetyl]-glucoside, 4'-O-methylhypolaetin 7-O-[6"'-O-acetyl]-allosyl- $(1 \rightarrow 2)-\left[6^{\prime \prime}-O\right.$-acetyl]-glucoside and 4'-O-methyl isoscutellarein $7-O-\left[6^{\prime \prime \prime}-O\right.$-acetyl]-allosyl- $(1 \rightarrow 2)-\left[6^{\prime \prime}-O\right.$ acetyl]-glucoside were previously isolated from 
Sideritis species and identified in the laboratory of the Institute of Organic Chemistry, Bulgarian Academy of Sciences, Sofia, Bulgaria, using NMR techniques [13].

\subsection{Preparation of \\ Sideritis scardica decoction}

The flowering plant of Sideritis scardica Griseb. (wild growing) was collected from Kozjak Mountain, R. Macedonia, in July 2011. $8 \mathrm{~g}$ of dried S. scardica sample was extracted with $400 \mathrm{ml}$ of boiling water during $10 \mathrm{~min}$ of boiling to the final volume of $300 \mathrm{ml}$. The phenolic composition of the sample was determined by LC-DAD-MS/MS.

Identification and peak assignment of all phenolic compounds was based on comparison of their retention times and mass spectral data with those of standards and published data.

\subsection{Study design}

Three male and seven female volunteers $(19-26$ years of age; mean body index $=24.2$, range $=18.4-29.7$ ) participated in the study divided in two stages. In stage 1 , they followed a polyphenols restricted diet (without fruits and vegetables, high-fiber products, and beverages: tea, coffee, fruit juices and wine) for 2 days before the study. After the wash period of 2 days, the volunteers consumed $300 \mathrm{ml}$ of the $S$. scardica decoction every morning in the next five days. Urine was collected over $24 \mathrm{~h}$ after ingestion of the drink. Urine samples were stored at $-80{ }^{\circ} \mathrm{C}$.

In stage 2 , the volunteers did not follow the flavonoids restricted diet, but continued with drinking $S$. scardica decoction, and collecting urine $24 \mathrm{~h}$ after ingestion of the drink.

\subsection{Urine extraction procedure for phenolic metabolites}

Phenolic metabolites in urine were extracted by solid-phase extraction (SPE). Prior to SPE, urine samples were centrifuged at $15000 \mathrm{~g}$ for $10 \mathrm{~min}$ at $4{ }^{\circ} \mathrm{C}$. After $5 \mathrm{~min}$ of vortex-mixing, $10 \mathrm{ml}$ urine sample was applied to the preconditioned C18 Sep-Peak cartridge (Waters, USA) with $5 \mathrm{ml}$ of methanol, $5 \mathrm{ml}$ of water and $5 \mathrm{ml}$ air. Sample clean up was performed with $3 \mathrm{ml}$ of water, followed by drying with $3 \mathrm{ml}$ air. Elution was performed with $3 \mathrm{ml}$ of methanol. The eluted fraction was concentrated to dryness and residues dissolved in $500 \mu \mathrm{l}$ of methanol.

\subsection{LC/DAD/ESI-MS analysis}

The native phenolic compounds present in $S$. scardica samples and the phenolic metabolites in urine samples were identified by LC-MS/MS analysis. Liquid chromatography separations were performed on Agilent Technologies 1100 LC system (Waldbronn, Germany) equipped with diode array and mass detector in series. It consisted of a G1312A binary pump, a G1329A auto-sampler, a G1379B degasser and G1315D photo-diode array detector, controlled by ChemStation software (Agilent, v.08.03).

Spectral data from all peaks were accumulated in range 190-600 $\mathrm{nm}$ and chromatograms were recorded at 280, 300 and $330 \mathrm{~nm}$.

For both analyses of plant and urine sample extracts XDB-Eclipse (Agilent, USA) C18 $(150 \mathrm{~mm} \times 4.6 \mathrm{~mm}, 5 \mu \mathrm{m})$ column was used at $38{ }^{\circ} \mathrm{C}$, with the sample injection volume of $20 \mu 1$.

Gradient elution was performed with a binary system consisting of (A) $1 \%$ aqueous formic acid and (B) methanol. A linear gradient starting with $20 \% \mathrm{~B}$ was installed to reach $80 \%$ $\mathrm{B}$ at $50 \mathrm{~min}$ and $100 \% \mathrm{~B}$ at $60 \mathrm{~min}$. The flow rate was $0.4 \mathrm{ml} \mathrm{min}^{-1}$.

The mass detector was a G2449A IonTrap Mass Spectrometer equipped with an electrospray ionization (ESI) system and controlled by LCMSD software (Agilent, v.6.1.). Nitrogen was used as nebulizing gas at pressure of $65 \mathrm{psi}$ and the flow was adjusted to $121 \mathrm{~min}^{-1}$. The heated capillary and the voltage were maintained at $350{ }^{\circ} \mathrm{C}$ and $4 \mathrm{kV}$, respectively. MS data were acquired in the negative ionization 
mode. The full scan covered the mass range at $m / z$ 100-1200. Collision-induced fragmentation experiments were performed in the ion trap using helium as collision gas, with voltage ramping cycle from 0.3 up to $2 \mathrm{~V}$. Maximum accumulation time of the ion trap and the number of MS repetitions to obtain the MS average spectra were set at $300 \mathrm{~ms}$ and 5, respectively.

\section{RESULTS AND DISCUSSION}

Relevant phenolic compounds in the $S$. scardica extracts were identified by their UV spectra, the deprotonated molecular ions and their corresponding ion fragments using LC-DAD-MS/MS (Table 1). Identification of phenolics was in accordance with previously reported work [6, 7]. Structures of the flavone aglycones from $S$. scardica decoction are given in Figure 1.

In $S$. scardica samples flavonoids are present in different chemical forms including aglycones, $\beta$-glycosides, $p$-coumaroyl and acetyl glycosides. Upon ingestion, the $\beta$-glycoside moiety is hydrolyzed by microbial $\beta$-glycosidase resulting in formation of the aglycones hypolaetin, metylhypolaetin, isoscutella- rein, 4'-O-methylisoscutellarein and apigenin. These compounds are then absorbed in the gut and transported to the liver. During absorption processes, flavonoids may be conjugated with glucuronic or sulfonic acid in hepatic and/or epithelial cell membranes (Figure 2) and can be bound to plasma proteins such as albumin [14]. Due to their hydrophilic characteristics compared to parent aglycones, the metabolites are more readily transported in the plasma and excreted into urine.

The bioavailability of flavonoids is influenced by multiple factors including: composition of intestinal microflora, gender, age, diet, duration of exposure and chemical and physical nature of the flavonoids and the food matrix. The extensive metabolism of flavonoids has been attributed to the action of intestinal microflora [15]. Hydrolytic enzymes of intestinal microflora can convert certain flavonoid glycosides (e.g. rutin) to their corresponding aglycones (e.g. quercetin), which could be further metabolized by intestinal microflora to various single-ring aromatic compounds $[15,16]$. Recently, however, intestinal hydrolysis of flavone monoglycosides was observed, suggesting that enterocytes might also play an important role in the hydrolysis of glycosides to aglycones [17].<smiles>[R3]c1ccc(-c2cc(=O)c3c(O)cc(O)c([R8])c3o2)cc1[R3]</smiles>

\begin{tabular}{lllll}
\hline Compounds: & $\mathrm{R}_{8}$ & $\mathrm{R}_{3^{\prime}}$ & $\mathrm{R}_{4^{\prime}}$ & $\mathrm{MW}$ \\
\hline luteolin & $\mathrm{H}$ & $\mathrm{OH}$ & $\mathrm{OH}$ & 286 \\
hypolaetin & $\mathrm{OH}$ & $\mathrm{OH}$ & $\mathrm{OH}$ & 302 \\
4'-O-methylhypolaetin & $\mathrm{OH}$ & $\mathrm{OH}$ & $\mathrm{OCH}_{3}$ & 316 \\
apigenin & $\mathrm{H}$ & $\mathrm{H}$ & $\mathrm{OH}$ & 270 \\
isoscutellarein & $\mathrm{OH}$ & $\mathrm{H}$ & $\mathrm{OH}$ & 286 \\
4'-O-methylisoscutellarein & $\mathrm{OH}$ & $\mathrm{H}$ & $\mathrm{OCH}_{3}$ & 300 \\
\hline
\end{tabular}

Fig. 1. Structures of flavone aglycones present in Sideritis scardica samples 


\section{Table 1}

Identification of phenolic compounds in Sideritis scardica extract by LC-DAD-MS/MS data

\begin{tabular}{|c|c|c|c|c|c|}
\hline & Compounds & $t_{\mathrm{R}}(\min )$ & UV (nm) & {$[\mathrm{M}-\mathrm{H}]^{-}(m / z)$} & $-\mathrm{MS}^{2}[\mathrm{M}-\mathrm{H}]^{-}(m / z)$ \\
\hline \multicolumn{6}{|c|}{ Hydroxycinnamic derivatives } \\
\hline 1 & 3-caffeoylquinic acid & 7.2 & 242,296 sh, 324 & 353 & $191 *, 179$ \\
\hline 2 & 5-caffeoylquinic acid & 12.0 & 242, 294sh, 326 & 353 & 191, 179 \\
\hline 3 & $p$-coumaric acid 4-O-glucoside & 14.3 & 232,312 & 325 & $\mathbf{3 0 7}, 265,235,217,187$ \\
\hline 4 & feruloylquinic acid & 16.6 & 295,322 & 367 & 191,173 \\
\hline \multicolumn{6}{|c|}{ Phenylethanoid glycosides } \\
\hline 5 & echinacoside & 19.9 & 232,246 sh, 290,332 & 785 & 623, 461 \\
\hline 6 & forsythoside B & 20.2 & $232,246,290,332$ & 755 & $623, \mathbf{5 9 3}, 461$ \\
\hline 7 & verbascoside & 20.6 & $232,244,290,302 \mathrm{sh}, 332$ & 623 & 487, 477, 461, 443, 315, 297 \\
\hline 8 & forsythoside A & 21.1 & $246,286,304,334$ & 623 & $578,463,461,445,316,301$ \\
\hline 10 & samioside & 22.4 & $234,246,288,330$ & 755 & $623, \mathbf{5 9 3}, 461$ \\
\hline 11 & isoverbascoside & 22.7 & $232,274,298 \mathrm{sh}, 358$ & 623 & 461, 315, 161 \\
\hline 12 & isoleucoseptoside & 23.1 & $234,288,330$ & 637 & $491, \mathbf{4 6 1}, 443,325$ \\
\hline 15 & allysonoside & 25.2 & $234,290,330$ & 769 & $637, \mathbf{5 9 3}, 575,491,475,461$ \\
\hline 16 & leucoseptoside A & 25.7 & $234,288,330$ & 637 & $491, \mathbf{4 6 1}, 443,325$ \\
\hline \multicolumn{6}{|c|}{ Luteolin derivatives } \\
\hline 17 & 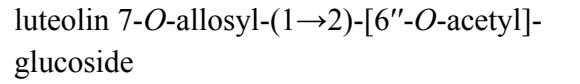 & 26.3 & 256,350 & 651 & $609,591,447,429,285$ \\
\hline 18 & $\begin{array}{l}\text { luteolin } 7-O-\left[6^{\prime \prime \prime}-O \text {-acetyl]-allosyl }(1 \rightarrow 2)\right. \\
\text { glucoside }\end{array}$ & 26.8 & 256,350 & 651 & $\mathbf{6 0 9}, 591,447,429,285$ \\
\hline 21 & $\begin{array}{l}\text { luteolin 7-O-[6"'-O-acetyl]-allosyl-( }(1 \rightarrow 2) \text { - } \\
{\left[6^{\prime \prime}-O \text {-acetyl]-glucoside }\right.}\end{array}$ & 28.4 & 256,352 & 693 & $\begin{array}{l}651,633,609,489,471 \\
429, \mathbf{2 8 5}\end{array}$ \\
\hline \multicolumn{6}{|c|}{ Hypolaetin derivatives } \\
\hline 9 & hypolaetin 7-O-allosyl $(1 \rightarrow 2)$ glucoside & 21.8 & 234,256 sh, $278,300,340$ & 625 & $463,445, \mathbf{3 0 1}$ \\
\hline 14 & $\begin{array}{l}\text { hypolaetin } 7-O-\left[6^{\prime \prime \prime}-O \text {-acetyl]-allosyl }(1 \rightarrow 2)\right. \\
\text { glucoside }\end{array}$ & 24.8 & $230,254,276,300,344$ & 667 & $\begin{array}{l}\mathbf{6 2 5}, 607,505,463,445, \\
301\end{array}$ \\
\hline 20 & $\begin{array}{l}\text { 3'-O-methylhypolaetin 7-O-allosyl-( }(1 \rightarrow 2) \text { - } \\
{\left[6^{\prime \prime}-O \text {-acetyl]-glucoside }\right.}\end{array}$ & 28.2 & $232,256,276,302,340$ & 681 & $\begin{array}{l}639,621,477,459, \mathbf{3 1 5} \\
301\end{array}$ \\
\hline 23 & $\begin{array}{l}\text { 4'-O-methylhypolaetin 7-O-[6"'-O-acetyl]- } \\
\text { allosyl }(1 \rightarrow 2) \text { glucoside }\end{array}$ & 30.3 & $226,254,276,302,340$ & 681 & $\begin{array}{l}\text { 639, } 621,477,459,315 \\
301\end{array}$ \\
\hline 24 & $\begin{array}{l}\text { hypolaetin } 7-O-\left[6^{\prime \prime \prime}-O \text {-acetyl]-allosyl- }\right. \\
(1 \rightarrow 2)-\left[6^{\prime \prime}-O \text {-acetyl]-glucoside }\right.\end{array}$ & 30.9 & $228,254,276,302,346$ & 709 & $\begin{array}{l}667,649,607,505,487 \\
427, \mathbf{3 0 1}\end{array}$ \\
\hline 29 & $\begin{array}{l}\text { 3'-O-methylhypolaetin 7-O-[6"'-O-acetyl]-} \\
\text { allosyl- }(1 \rightarrow 2)-\left[6^{\prime \prime}-O \text {-acetyl]-glucoside }\right.\end{array}$ & 33.6 & $228,256,276,302,340$ & 723 & $\begin{array}{l}\mathbf{6 8 1}, 663,639,621,477 \\
315,301\end{array}$ \\
\hline \multicolumn{6}{|c|}{ Apigenin derivatives } \\
\hline 26 & apigenin 7-(6"-p-coumaroylglucoside) & 32.9 & $232,268,318$ & 577 & 431, 413, 307, 269 \\
\hline 27 & apigenin 7-(4"-p-coumaroylglucoside) & 33.2 & $232,270,318$ & 577 & 431, 413, 307, 269 \\
\hline \multicolumn{6}{|c|}{ Isoscutellarein derivatives } \\
\hline 13 & isoscutellarein 7-O-allosyl $(1 \rightarrow 2)$ glucoside & 23.7 & $230,274,306,328$ & 609 & $447,429, \mathbf{2 8 5}$ \\
\hline 19 & $\begin{array}{l}\text { isoscutellarein } 7-O-\left[6^{\prime \prime \prime}-O \text {-acetyl }\right]- \\
\text { allosyl }(1 \rightarrow 2) \text { glucoside }\end{array}$ & 27.1 & $230,276,306,330$ & 651 & 609, 591, 447, 429, 285 \\
\hline 22 & $\begin{array}{l}\text { 4'-O-methylisoscutellarein } \\
\text { 7-O-allosyl }(1 \rightarrow 2) \text { glucoside }\end{array}$ & 29.1 & $230,292,314$ & 623 & $461,443,299$ \\
\hline 25 & $\begin{array}{l}\text { 4'-O-methylisoscutellarein 7-O-allosyl- } \\
(1 \rightarrow 2)-\left[6^{\prime \prime}-O \text {-acetyl]-glucoside }\right.\end{array}$ & 32.2 & $230,276,306,328$ & 665 & $\begin{array}{l}623,503,461,443,299 \\
285\end{array}$ \\
\hline 28 & $\begin{array}{l}\text { isoscutellarein 7-O-[6"'-O-acetyl]-allosyl- } \\
(1 \rightarrow 2)-\left[6^{\prime \prime}-O \text {-acetyl]-glucoside }\right.\end{array}$ & 33.2 & $230,276,308,328$ & 693 & $\begin{array}{l}651,633,609,489,471 \\
429, \mathbf{2 8 5}\end{array}$ \\
\hline 30 & $\begin{array}{l}\text { 4'-O-methylisoscutellarein 7-O-[6"'-O- } \\
\text { acetyl]-allosyl }(1 \rightarrow 2) \text { glucoside }\end{array}$ & 34.4 & $230,276,306,328$ & 665 & $\begin{array}{l}\mathbf{6 2 3}, 503,461,443,299 \\
284\end{array}$ \\
\hline 31 & $\begin{array}{l}\text { 4'-O-methylisoscutellarein 7-O-[6"'-O- } \\
\text { acetyl]-allosyl- }(1 \rightarrow 2)-\left[6^{\prime \prime}-O \text {-acetyl]- }\right. \\
\text { glucoside }\end{array}$ & 36.9 & $230,280,306,330$ & 707 & $\begin{array}{l}\text { 665, } 647,605,545,503 \\
\mathbf{2 9 9}, 284\end{array}$ \\
\hline
\end{tabular}

* The $m / z$ value for the base peak is in bold

Maced. J. Chem. Chem. Eng. 31 (2), 231-245 (2012) 


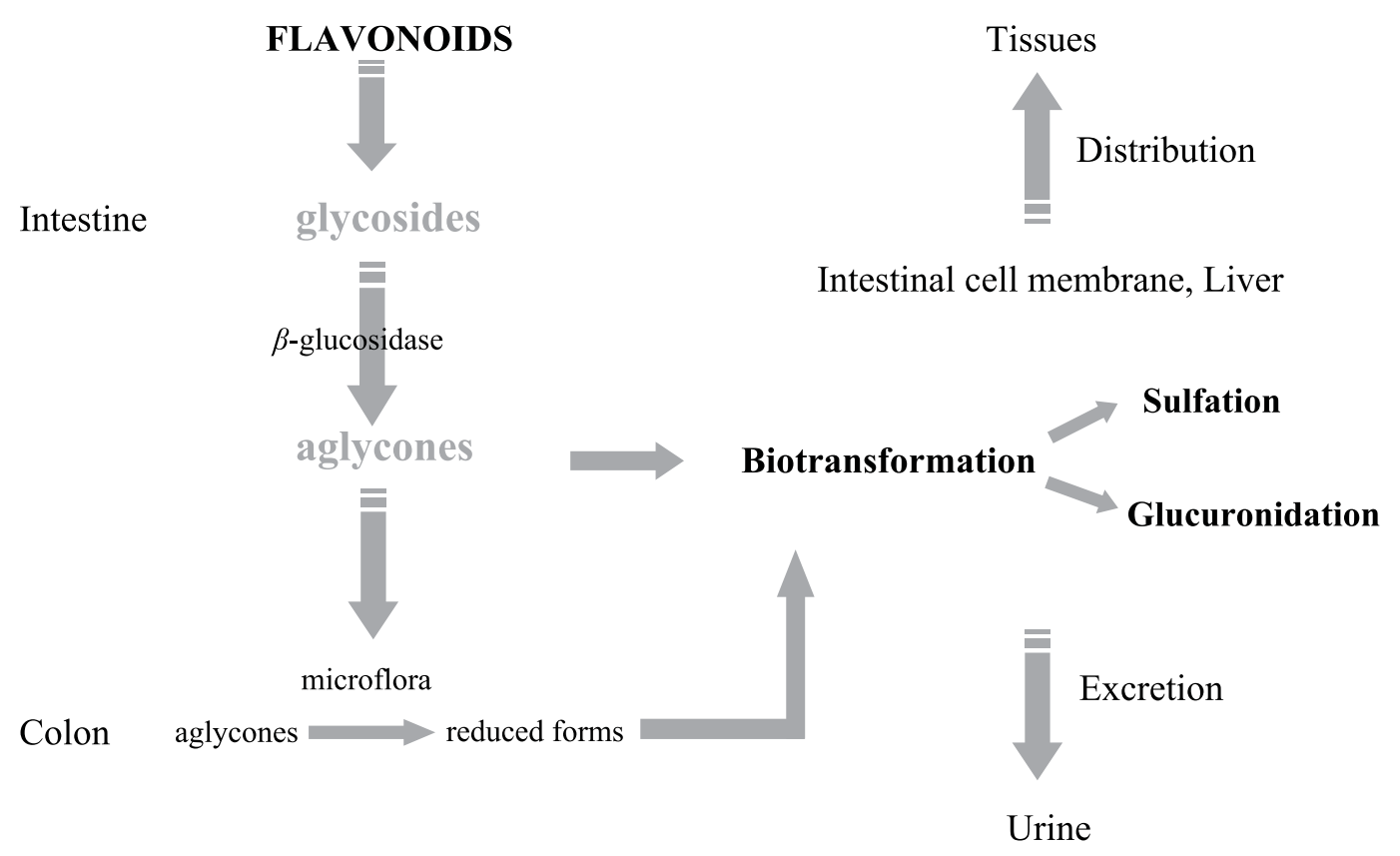

Fig. 2. General scheme for the absorption and metabolism of flavonoids

\subsection{Flavonoid metabolites}

$\mathrm{HPLC} / \mathrm{MS}^{2}$ and $\mathrm{MS}^{3}$ was used to identify the metabolites of hydroxycinnamic acids, phenylethanoid glycosides and flavonoids from $S$. scardica excreted in urine collected 24 hours after ingestion. Phenolic metabolites identified in urine are listed in Table 2 and Table 3. Analysis of phenolic metabolites is more subtle than generally appreciated. This is due to the fact that, without reference compounds that can be separated by reversed phase HPLC, it is impossible to distinguish between 3'-O-methylhypolaetin and 4'-O-methylhypolaetin by mass spectrometry, as well as to locate the position of glucuronidation or sulfation. So, here we refer to metabolites as glucuronide, sulfate and glucuronide-sulfate without specifying the position of substitution.

A total of 31 different metabolites of hypolaetin, methylhypolaetin, isoscutellarein, 4'-O-methylisoscutellarein and apigenin were detected in the urine samples (Table 2).

Peaks M3, M5, M6 and M18 showed pseudomolecular ions at $\mathrm{m} / \mathrm{z} 395,395,381$ and 365, respectively, which yielded $m / z 315,315,301$ and 285 after loss of 80 amu (sulphate moiety) (Figure 3a). They were identified as methylhypolaetin sulfate (M3, M5), hypolaetin sulfate (M6) and isoscutellarein sulfate (M18).

Peaks M16, M62 and M63 were identified by their $[\mathrm{M}-\mathrm{H}]^{-} \mathrm{m} / \mathrm{z}$ at 429,459 and 459 , respectively. The initial $\mathrm{MS}^{2}$ loss of 80 amu corresponds to one sulfate moiety and gave main product ion at $m / z 349,379$ and 379 (Figure 3b). The fragments at $\mathrm{m} / \mathrm{z} 269,299$ and 299 correspond to aglycones of apigenin and 4'-Omethylisoscutellarein. Therefore M16 is presumably a disulfated apigenin, whereas $\mathbf{M 6 2}$ and $\mathbf{M 6 3}$ disulfated 4'- $O$-methylisoscutellarein.

Peaks M7, M8, M10, M15, M17, M19, M23, M43, M46, M56 and M58 produced [M$\mathrm{H}]^{-} \mathrm{m} / \mathrm{z}$ at 477 (M8, M17, M19), 491 (M56, M58), 461 (M43, M46), 475 (M7, M10) and 445 (M15, M23), respectively. After loss of $176 \mathrm{amu}$ (a glucuronide unit) (Figure 3c) they gave ions at $m / z 301,315,285,299$ and 269, respectively, which characterize these compounds as glucuronides of hypolaetin (M8, M17, M19), methylhypolaetin (M56, M58), isoscutellarein (M43, M46), 4'-O-methylisoscutellarein (M7, M10) and apigenin (M15, M23). 
Table 2

$H P L C-M S^{2}$ data for identification of flavonoid metabolites in urine collected 0-24 h after ingestion of mountain tea

\begin{tabular}{|c|c|c|c|c|c|}
\hline Peak & $\begin{array}{l}t_{\mathrm{R}} / \\
\min \end{array}$ & {$[\mathrm{M}-\mathrm{H}]^{-}(\mathrm{m} / z)$} & $\mathrm{MS}^{2}$ & \multicolumn{2}{|c|}{ Compound } \\
\hline \multicolumn{6}{|c|}{ Hypolaetin derivatives } \\
\hline M6 & 24.3 & 381 & 301* & hypolaetin & sulfate \\
\hline M8 & 24.4 & 477 & $459, \mathbf{3 0 1}$ & hypolaetin & glucuronide \\
\hline M17 & 31 & 477 & $459, \mathbf{3 0 1}$ & hypolaetin & glucuronide \\
\hline M19 & 31.8 & 477 & $459, \mathbf{3 0 1}$ & hypolaetin & glucuronide \\
\hline M40 & 37.3 & 653 & $477,459,301$ & hypolaetin & diglucuronide \\
\hline M11 & 25.5 & 557 & $447, \mathbf{3 0 1}$ & hypolaetin & glucuronide-sulfate \\
\hline M3 & 21.8 & 395 & 315 & methylhypolaetin & sulfate \\
\hline M5 & 24.1 & 395 & 315 & methylhypolaetin & sulfate \\
\hline M56 & 43.6 & 491 & $473,447,315$ & methylhypolaetin & glucuronide \\
\hline M58 & 44.6 & 491 & $473,447, \mathbf{3 1 5}$ & methylhypolaetin & glucuronide \\
\hline M44 & 38.5 & 623 & 447,315 & methylhypolaetin & glucuronide + pentose \\
\hline \multicolumn{6}{|c|}{ Isoscutellarein derivatives } \\
\hline M18 & 31.7 & 365 & 285 & isoscutellarein & sulfate \\
\hline M43 & 38.3 & 461 & $443, \mathbf{2 8 5}$ & isoscutellarein & glucuronide \\
\hline M46 & 39.7 & 461 & 443,285 & isoscutellarein & glucuronide \\
\hline M24 & 32.7 & 541 & 461, 285 & isoscutellarein & glucuronide-sulfate \\
\hline M27 & 33.3 & 541 & 461, 285 & isoscutellarein & glucuronide-sulfate \\
\hline M29 & 34.5 & 541 & 461,285 & isoscutellarein & glucuronide-sulfate \\
\hline M32 & 35.1 & 541 & 461,285 & isoscutellarein & glucuronide-sulfate \\
\hline M62 & 49.2 & 459 & 379, 299 & methylisoscutellarein & disulfate \\
\hline M63 & 49.7 & 459 & 379, 299 & methylisoscutellarein & disulfate \\
\hline M7 & 24.3 & 475 & 457,299 & methylisoscutellarein & glucuronide \\
\hline M10 & 25.4 & 475 & 457,299 & methylisoscutellarein & glucuronide \\
\hline M4 & 23.3 & 651 & $475,457,299$ & methylisoscutellarein & diglucuronide \\
\hline M41 & 37.5 & 651 & 475, 299 & methylisoscutellarein & diglucuronide \\
\hline \multicolumn{6}{|c|}{ Apigenin derivatives } \\
\hline M16 & 28.5 & 429 & 349,269 & apigenin & disulfate \\
\hline M15 & 28.5 & 445 & 269 & apigenin & glucuronide \\
\hline M23 & 32.6 & 445 & 269 & apigenin & glucuronide \\
\hline M53 & 42.4 & 621 & $\mathbf{4 4 5}, 427,269$ & apigenin & diglucuronide \\
\hline M28 & 34.0 & 525 & $\mathbf{4 4 5}, 269$ & apigenin & glucuronide-sulfate \\
\hline M36 & 36.5 & 525 & $445, \mathbf{2 6 9}$ & apigenin & glucuronide-sulfate \\
\hline M45 & 38.6 & 525 & 445,269 & apigenin & glucuronide-sulfate \\
\hline
\end{tabular}

* The $m / z$ value for the base peak is in bold 
Peaks M40 and M41 showed deprotonated molecular ions $[\mathrm{M}-\mathrm{H}]^{-}$at $m / z 653$ and 651 respectively. The $\mathrm{MS}^{2}$ spectra of these ions yielded the base peak [M-H-176] ${ }^{-}(\mathrm{m} / z 477$ and 475) corresponding to the loss of glucuronide residue (Figure $3 \mathrm{~d}$ ). In the $\mathrm{MS}^{3}$ spectra of these compounds the base peak was derived from a second loss of $176 \mathrm{amu}(\mathrm{m} / \mathrm{z} 301$ and 299). Therefore, these compounds could be characterized as hypolaetin (M40) and 4'-Omethylisoscutellarein (M41) diglucuronides with two glucuronide units bonded to the aglycone in different positions supported by their consecutive loss evidenced in $\mathrm{MS}^{2}$ and $\mathrm{MS}^{3}$. In contrast, after $\mathrm{MS}^{2}$ fragmentation of compound M4, the base peak was detected after the loss of 352 amu (2 glucuronide units) from the deprotonated ion (Figure 3e). The occurrence of [M-H-176] $]^{-}$ions $(\mathrm{m} / \mathrm{z} 475$ and 457) implied the presence of glucuronide residue. Thus, M4 was also characterized as 4'-O-methylisoscutellarein diglucuronide, but with substitution in one position in the aglycone i.e. glucuronide moieties attached to each other.

Peaks M11, M29, M32, M36 and M45 had $[\mathrm{M}-\mathrm{H}]^{-}$ions at $\mathrm{m} / z 557$ (M11), 541 (M29, M32), 525 (M36, M45) and $\mathrm{MS}^{2}$ produced sequential losses of 80, 176 and 256 amu indicating the presence of a glucuronide/sulfate conju- gate (Figure $3 \mathrm{f}$ ). The aglycone ions at $\mathrm{m} / \mathrm{z} 301$ (M11), 285 (M29, M32) and 269 (M36, M45) were hypolaetin, isoscutellarein and apigenin. These three metabolities are therefore hypolaetin- $O$-glucuronide- $O$-sulfate (M11), isoscutellarein- $O$-glucuronide- $O$-sulfate $(\mathbf{M 2 9}, \mathbf{M 3 2})$ and apigenin- $O$-glucuronide- $O$-sulfate (M36, M45).

Peaks M24, M27 and M28 produced deprotonated molecular ions $[\mathrm{M}-\mathrm{H}]^{-}$at $\mathrm{m} / \mathrm{z} 541$ (M24, M27) and 525 (M28). The $\mathrm{MS}^{2}$ spectra of these ions yielded the base peak [M-H-80] corresponding to the loss of sulfate moiety. In their $\mathrm{MS}^{3}$ spectra, the base peak was derived from a loss of $176 \mathrm{amu}$ (glucuronide residue), typical for $O$-conjugated compounds in two positions on the flavonoid skeleton (Figure $3 \mathrm{~g}$ ).

These compounds could be characterized as isoscutellarein- $O$-glucuronide- $O$-sulfate (M24, M27) and apigenin- $O$-glucuronide- $O$ sulfate (M28) but the glucuronide and sulfate moities are linked in different positions on the aglycone.

Peak M44 had an $[\mathrm{M}-\mathrm{H}]^{-}$ion at $\mathrm{m} / z 623$ and $\mathrm{MS}^{2}$ fragmentation resulted in a $176 \mathrm{amu}$ loss of a glucuronyl group followed by loss of pentose unit (Figure 3h). This metabolite can be identified as methylhypolaetin pentoside glucuronide.

(a)

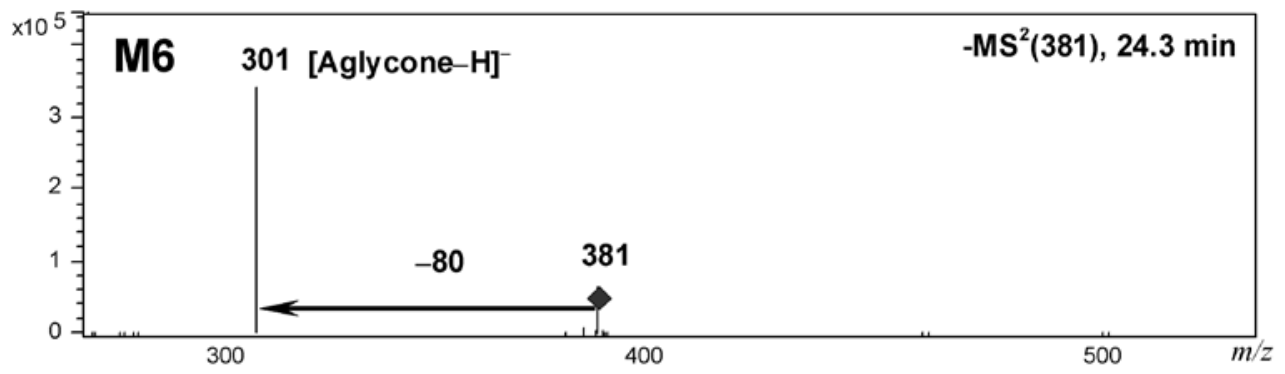

(b)

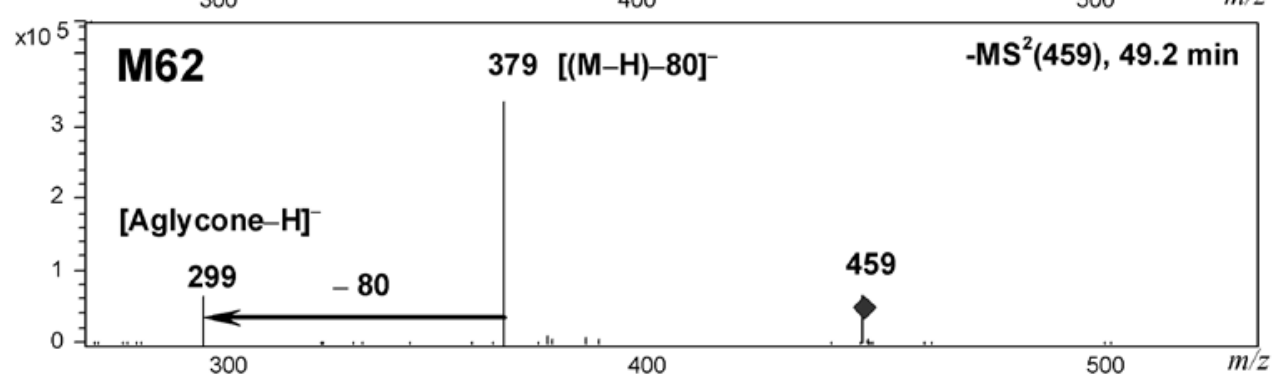

Fig. 3. $\mathrm{MS}^{2}$ spectra of some characteristic metabolites of flavonoids present in urine (a) hypolaetin sulfate; (b) 4'-O-methylisoscutellarein disulfate 
(c)

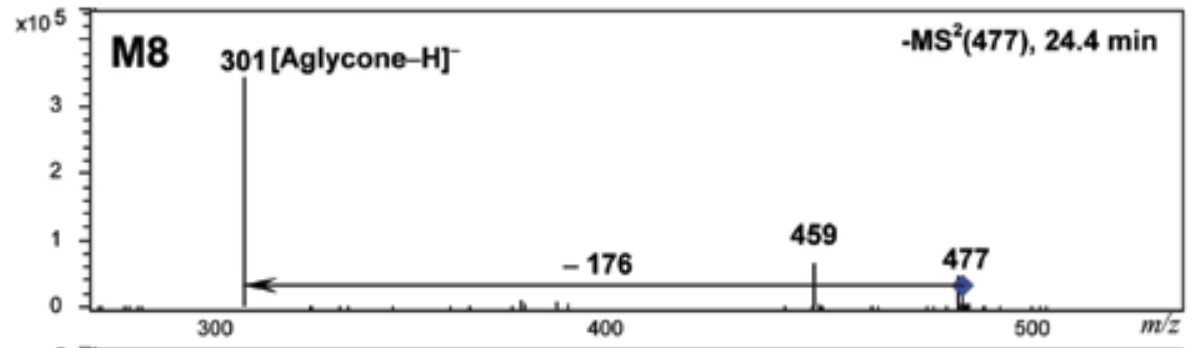

(d)

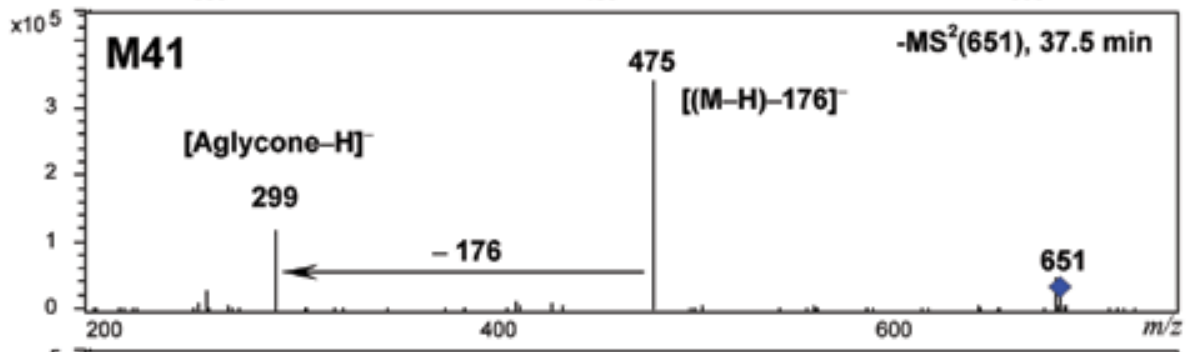

(e)

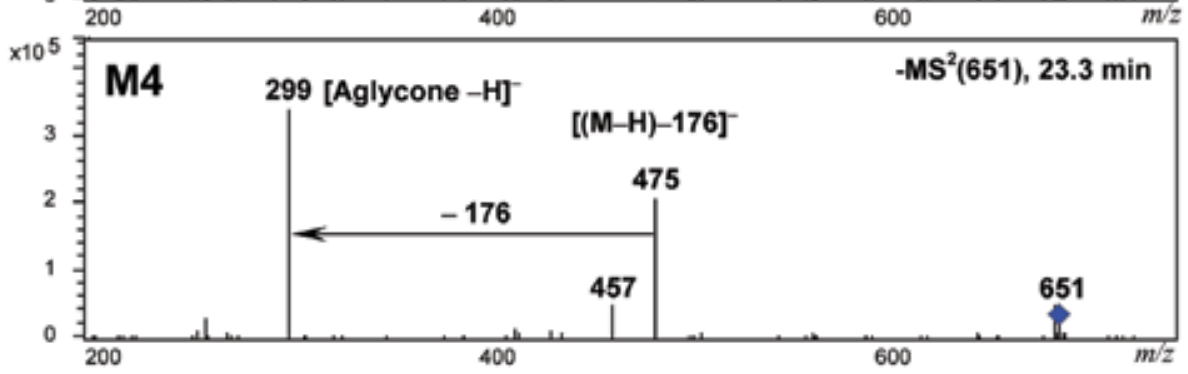

(f)

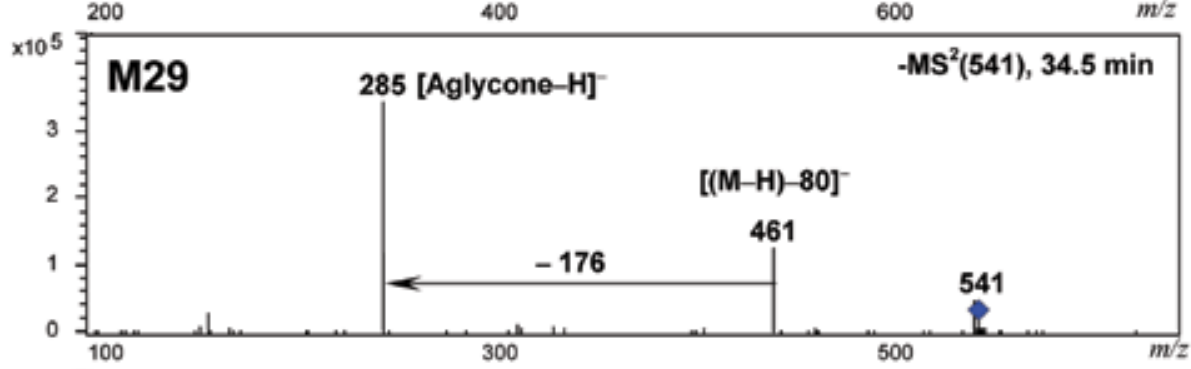

(g)
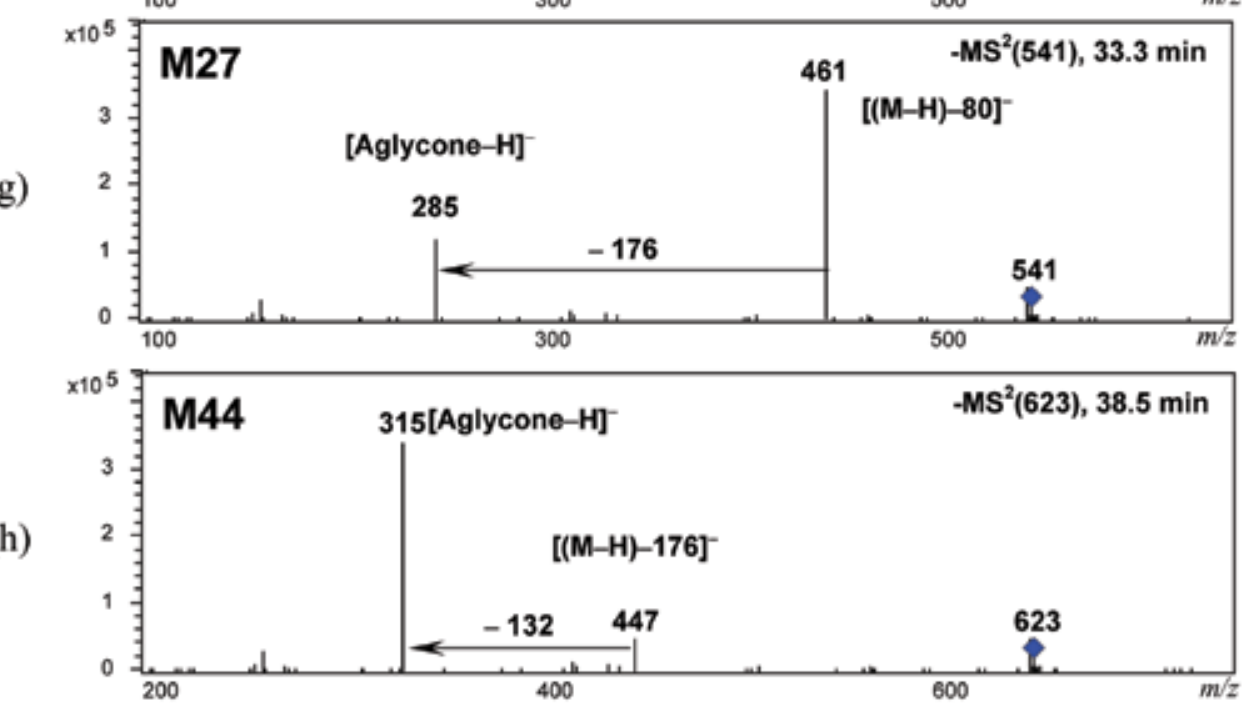

Fig. 3. $\mathrm{MS}^{2}$ spectra of some characteristic metabolites of flavonoids present in urine

(c) hypolaetin glucuronide; (d, e) 4'-O- methylisoscutellarein diglucuronide; (f, g) isoscutellarein glucuronide-sulfate and (h) methylhypolaetin glucuronyl-pentoside 
T a b 1 e 3

HPLC-MS ${ }^{2}$ identification of phenolic acids metabolites in urine collected 0-24 h after ingestion of mountain tea

\begin{tabular}{|c|c|c|c|c|c|}
\hline Peak & $t_{\mathrm{R}} / \min$ & {$[\mathrm{M}-\mathrm{H}]^{-}(m / z)$} & $\mathrm{MS}^{2}$ & \multicolumn{2}{|l|}{ Compound } \\
\hline \multicolumn{6}{|c|}{ Quinic acid derivatives } \\
\hline M22 & 32.4 & 431 & $351 *, 271,191$ & quinic acid & trisulfate \\
\hline M30 & 34.6 & 367 & 191 & quinic acid & glucuronide \\
\hline M61 & 48.6 & 367 & 191 & quinic acid & glucuronide \\
\hline M51 & 41.5 & 447 & 367,191 & quinic acid & glucuronide-sulfate \\
\hline M59 & 46.7 & 447 & 271,191 & quinic acid & glucuronide-sulfate \\
\hline \multicolumn{6}{|c|}{ Caffeic acid derivatives } \\
\hline M2 & 15.6 & 179 & 161 & caffeic acid & \\
\hline M39 & 37.1 & 435 & 259,179 & caffeic acid & glucuronide-sulfate \\
\hline M12 & 27.7 & 383 & $\mathbf{2 0 7}, 179$ & dimethylcaffeic acid & glucuronide \\
\hline M14 & 28.1 & 383 & $\mathbf{2 0 7}, 179$ & dimethylcaffeic acid & glucuronide \\
\hline \multicolumn{6}{|c|}{ Chlorogenic acid derivatives } \\
\hline M26 & 33.1 & 433 & 353, 179 & chlorogenic acid & sulfate \\
\hline M31 & 35.0 & 433 & 353,179 & chlorogenic acid & sulfate \\
\hline M54 & 42.5 & 513 & 433, 353 & chlorogenic acid & disulfate \\
\hline M55 & 42.9 & 513 & $433, \mathbf{3 5 3}$ & chlorogenic acid & disulfate \\
\hline M47 & 39.7 & 529 & 353,179 & chlorogenic acid & glucuronide \\
\hline M48 & 40.2 & 529 & 353, 179 & chlorogenic acid & glucuronide \\
\hline M49 & 40.9 & 529 & $\mathbf{3 5 3}, 179$ & chlorogenic acid & glucuronide \\
\hline \multicolumn{6}{|c|}{ Ferulic acid derivatives } \\
\hline M13 & 27.9 & 273 & 193 & ferulic acid & sulfate \\
\hline M20 & 31.9 & 369 & 193 & ferulic acid & glucuronide \\
\hline M33 & 35.2 & 369 & 193 & ferulic acid & glucuronide \\
\hline M38 & 36.9 & 369 & 193 & ferulic acid & glucuronide \\
\hline M42 & 37.5 & 369 & 193 & ferulic acid & glucuronide \\
\hline M25 & 32.8 & 449 & 369,193 & ferulic acid & glucuronide-sulfate \\
\hline M50 & 41.3 & 449 & 369,193 & ferulic acid & glucuronide-sulfate \\
\hline M60 & 47.3 & 449 & 369,193 & ferulic acid & glucuronide-sulfate \\
\hline M9 & 24.4 & 301 & $\mathbf{2 7 3}, 193$ & dimethylferulic acid & sulfate \\
\hline M1 & 13.8 & 397 & $\mathbf{2 2 1}, 193$ & dimethylferulic acid & glucuronide \\
\hline M35 & 35.6 & 397 & $\mathbf{2 2 1}, 193$ & dimethylferulic acid & glucuronide \\
\hline M34 & 35.5 & 527 & $447, \mathbf{3 6 7}$ & feryoil quinic acid & disulfate \\
\hline M21 & 32.4 & 543 & 367 & feryoil quinic acid & glucuronide \\
\hline M37 & 36.5 & 571 & $395, \mathbf{3 6 7}$ & $\begin{array}{l}\text { dimethylferyoil } \\
\text { quinic acid }\end{array}$ & glucuronide \\
\hline \multicolumn{6}{|c|}{ Coumaric acid derivatives } \\
\hline M52 & 41.9 & 513 & 337 & coumaric acid & glucuronide \\
\hline M57 & 43.7 & 513 & 337 & coumaric acid & glucuronide \\
\hline
\end{tabular}

* The $m / z$ value for the base peak is in bold 


\subsection{Phenolic acids metabolites}

A total of 32 phenolic acid metabolites were identified in urine samples after $24 \mathrm{~h}$ excretion (Table 3). Peak M2 had [M-H] $]^{-}$ions at $m / z 179$, which fragmented in $\mathrm{MS}^{2}$ to $m / z 161$. This fragmentation pattern is characteristic for caffeic acid.

Peaks M13, M26 and M31 had [M-H] ions at $m / z 273$ (M13) and 433 (M26, M31) which led to $m / z 193$ (M13) in $\mathrm{MS}^{2}$, the molecular ion of ferrulic acid and $\mathrm{m} / \mathrm{z} 353$ and 179 (M26, M31) the molecular ions characteristic for chlorogenic acid (Figure 4a). These metabolites were identified as ferulic acid sulfate and chlorogenic acid sulfate.

Peak M9 had $[\mathrm{M}-\mathrm{H}]^{-}$ion and $\mathrm{MS}^{2}$ spectrum for $28 \mathrm{amu}$ higher than that of M13. The main $\mathrm{MS}^{2}$ fragment $\left(m / z\right.$ 273) had an $\mathrm{MS}^{3}$ spectrum characteristic of ferulic acid (ions at $m / z 193,179,149$ and 135), which identified this compound as dimethylferulic acid sulfate.

Peaks M22, M34, M54 and M55 had $[\mathrm{M}-\mathrm{H}]^{-}$ions at $\mathrm{m} / z 431$ (M22), 527 (M34) and 513 (M54, M55), which yielded MS $^{2}$ fragment ions at $\mathrm{m} / \mathrm{z} 351,271$ and 191 (M22) obtained by sequential losses of 80,160 and 240 amu indicating the presence of three sulfate groups (Figure 4c), and at $\mathrm{m} / \mathrm{z} 447,367$ for M34 and 433, 353 (M54, M55) - losses of 80 and $160 \mathrm{amu}$ indicating the presence of two sulfate groups (Figure $4 \mathrm{~b}$ ). These MS spectra characterized these compounds as quinic acid trisulfate (M22), feruloylquinic acid disulfate (M34) and chlorogenic acid disulfate (M54, M55).

Peaks M1, M12, M14, M20, M21, M30, M33, M35, M37, M38, M42, M47, M48, M49, M52, M57 and M61 had neutral loss of $176 \mathrm{amu}$ (Figure 4d and 4e). The fragments at m/z 191 (M30, M61), 193 (M20, M33, M38, M42), 207, 179 (M12, M14), 353, 179 (M47, M48, M49), 221, 193 (M1, M35), 367 (M21), 337 (M52, M57) and 395, 367 (M37) correspond to quinic acid (M30, M61), ferulic acid (M20, M33, M38, M42), dimethylcaffeic acid (M12, M14), chlorogenic acid (M47, M48, M49), dimethylferulic acid (M1, M35), feruloylquinic acid (M21), coumaric acid (M52, M57) and dimethylferuloylquinic acid (M37).

Peaks M25, M39, M51, M50, M59 and M60 had [M-H]- ions at $m / z 435$ (M39), 447 (M51, M59) and 449 (M25, M50, M60). The neutral losses of 80 and 176 indicated cleavage of both sulfate and glucuronide moiety. These compounds were identified as caffeic acid glucuronide-sulfate (M39), quinic acid glucuronide-sulfate (M51, M59) and ferulic acid glucuronide-sulfate (M25, M50, M60) (Figure $4 \mathrm{f}$ and $4 \mathrm{~g}$ ).

(a)

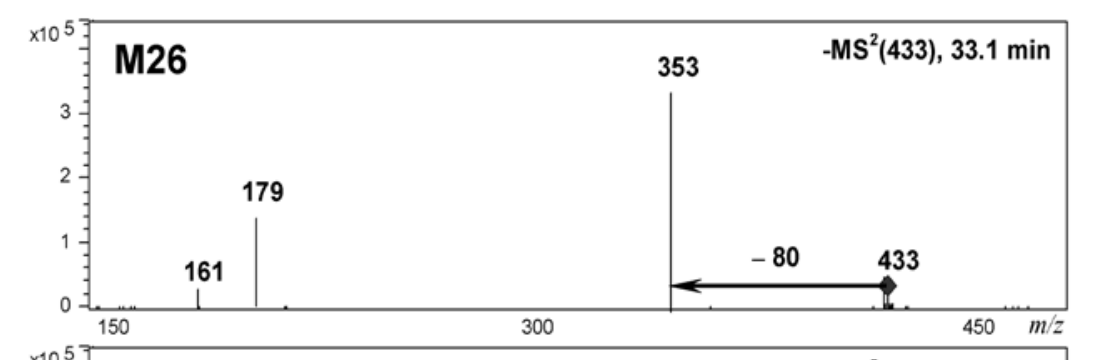

(b)

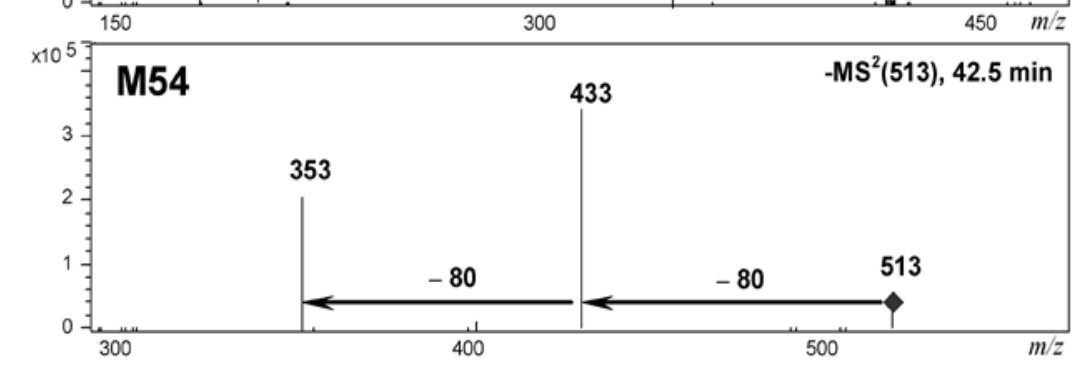

Fig.4. $\mathrm{MS}^{2}$ spectra of some characteristic metabolites of phenolic acids present in urine (a) chlorogenic acid sulfate; (b) chlorogenic acid disulfate 
(c)

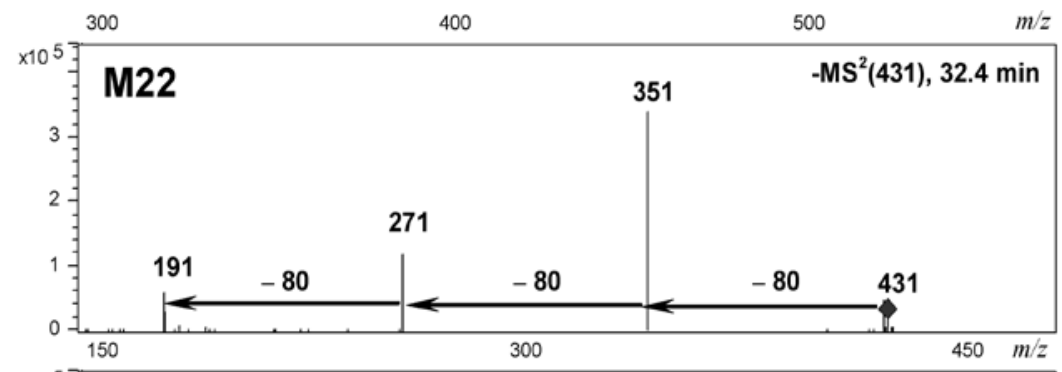

(d)

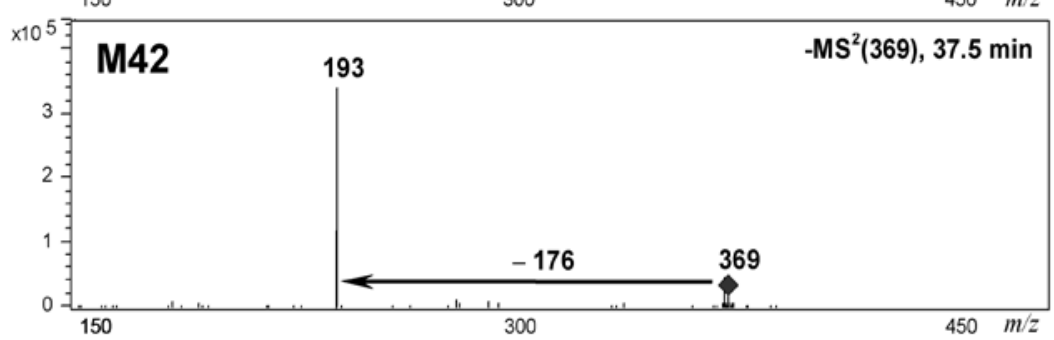

(e)

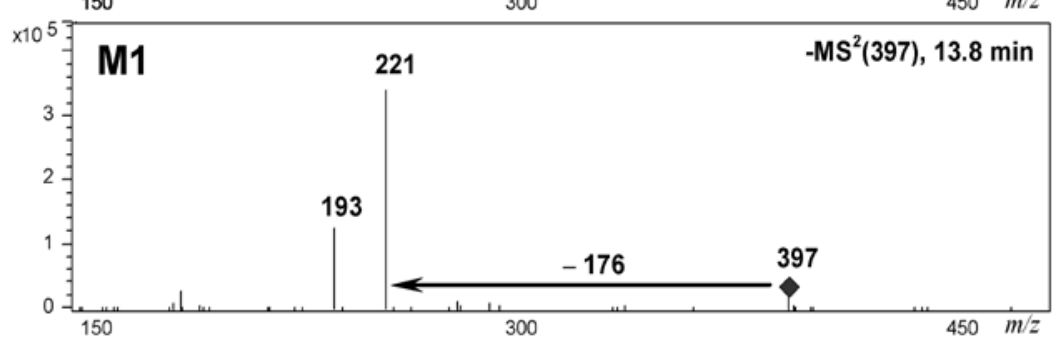

(f)
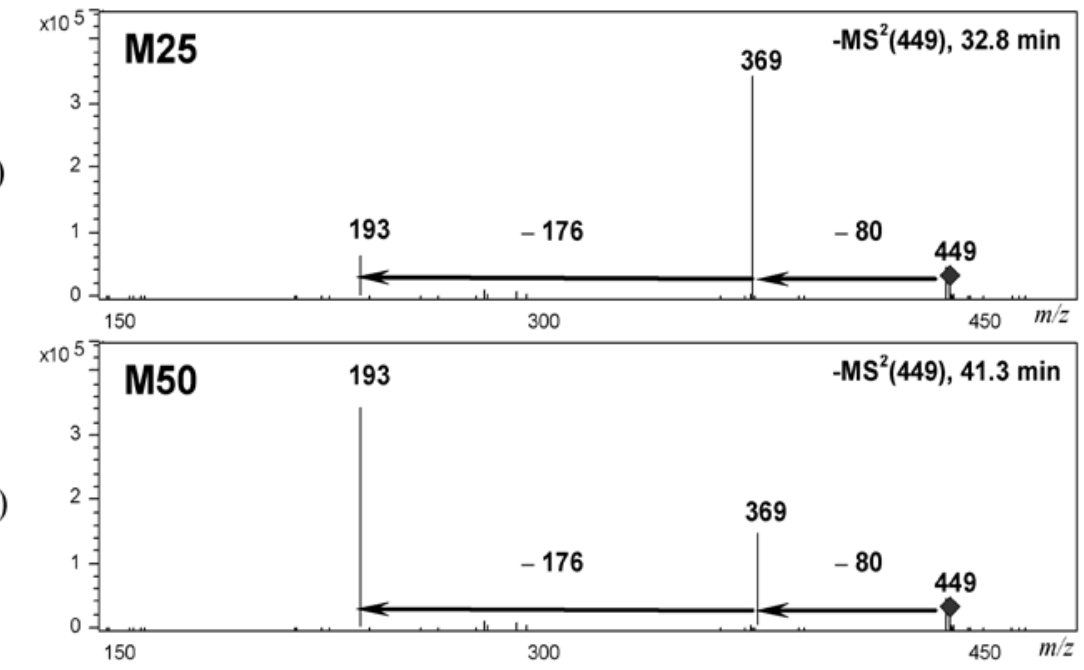

Fig.4. $\mathrm{MS}^{2}$ spectra of some characteristic metabolites of phenolic acids present in urine (c) quinic acid trisulfate (d) ferulic acid glucuronide; (e) dimethylferulic acid glucuronide;

\section{$(f, g)$ ferulic acid glucuronide-sulfate}

\subsection{Polyphenols metabolites occurrence}

In the $S$. scardica decoction a total of 31 compounds were identified which were classified in six groups of polyphenols: hydroxycinnamic acid derivatives, phenylethanoid glycosides, luteolin, hypolaetin, apigenin and isoscutellaerin derivatives (Table 1). In contrast, in urine samples, a total of 63 different metabolites were detected implying that these compounds are subjected to different metabolic pathways. Following the prior grouping, the metabolites can be summarized in four groups as follows: hypolaetin, isoscutellaerin and apigenin derivatives, and phenolic acids derivatives (quinic acid, caffeic acid, chlorogenic acid, ferrulic acid and coumaric acid) as presented in Table 2 and Table 3. 
By in vivo experiments performed in this work, it was shown that phenolic compounds present in $S$. scardica decoction are extensively conjugated to glucuronides, sulfates and also transformed to methylated forms after their oral administration. Upon ingestion, the $\beta$-glycosides are hydrolyzed by microbial $\beta$-glycosidase resulting in the formation of the aglycones hypolaetin, metylhypolaetin, isiscutellarein, 4'-O-methylisoscutellarein and apigenin, which are subsequently absorbed in the gut and transported to the liver. After drinking a standardized extract of mountain tea, 31 different metabolites of hypolaetin, methylhypolaetin, isoscutellarein, 4'-O-methylisoscutellarein and apigenin, and 32 phenolic acid metabolites were detected in the urine samples.
Hypolaetin and isoscutellarein were the dominant groups present in the urine with the highest number of different metabolites. These two types of flavones are quite specific for the genus $S$. scardica which are not so abundant in of the plant derived food in contrast to apigenin and luteolin, so there were not significant differences in the samples when the non-flavonoid diet was or was not followed. A total of eleven hypolaetin metabolites were present in urine; six of them were hypolaetin derivatives (M6, M8, M17, M19, M40, M11) and five methylhypolaetin derivatives (M3, M5, M56, M58, M44). In the $S$. scardica decoction, hypolaetin was present with nine derivatives: six hypolaetin and three methylhypolaetin derivatives. As can be seen in Figure 5a, compounds M11 (hypolaetin glucuronide-sulfate), M56

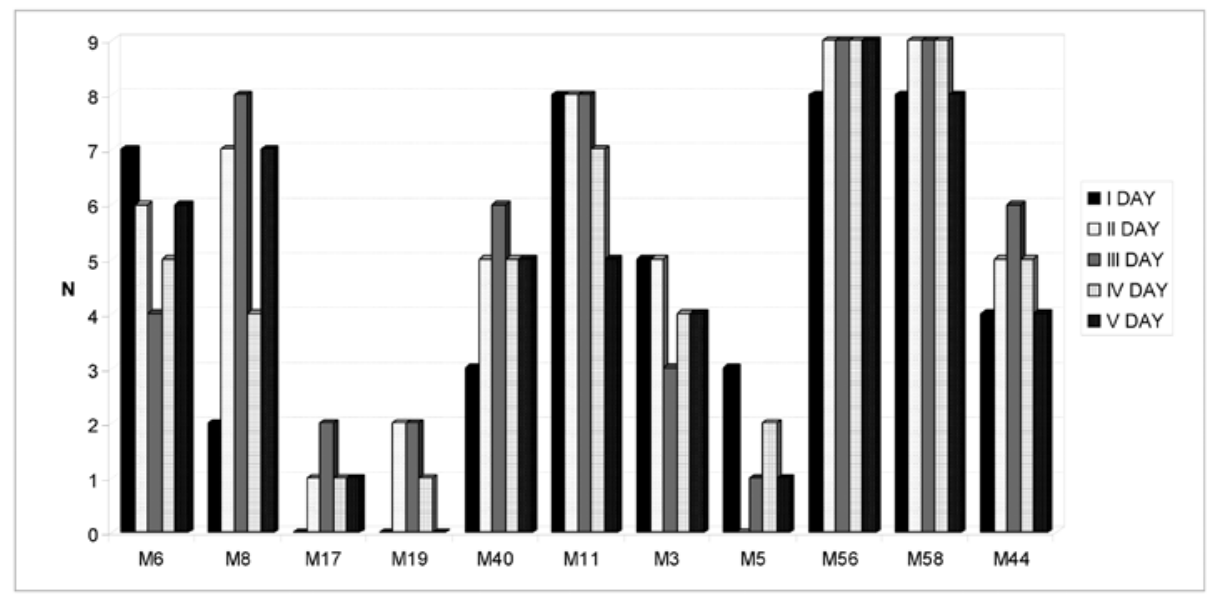

(a)

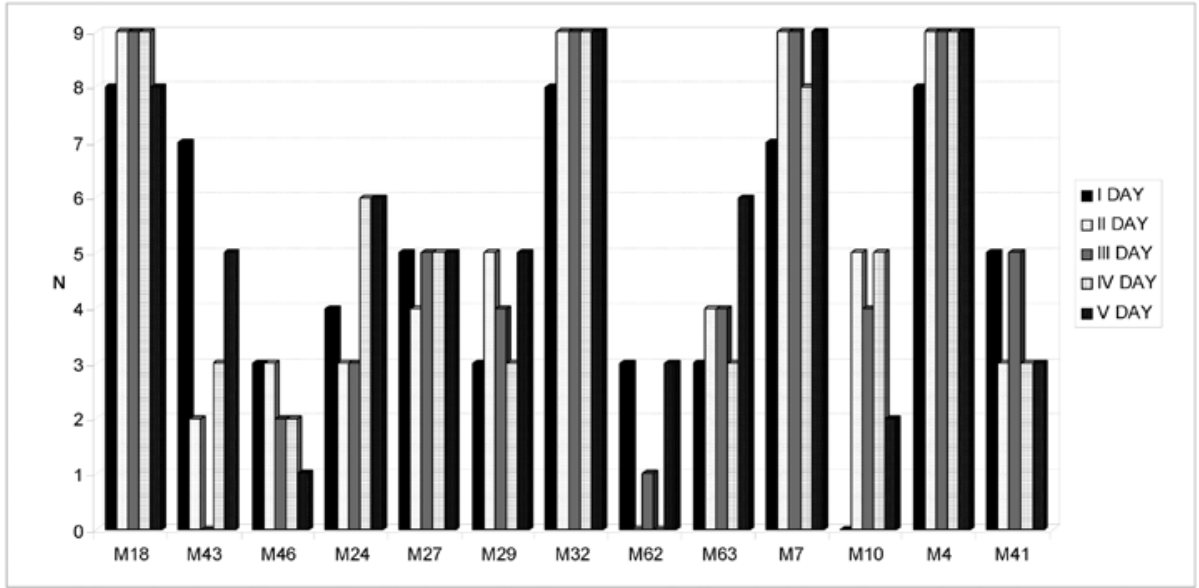

(b)

Fig. 5. Distribution of (a) hypolaetin derivatives, and (b) isoscutellarein derivatives per day in urine samples of 9 volunteers $(\mathrm{N})$ 
and M57 (methylhypolaetin glucuronide) were the most abundant metabolites detected in the urine samples of volunteers in the different days of the study.

Isoscutellarein derivatives were present as thirteen different metabolites; seven isoscutellarein derivatives (M18, M43, M46, M24, M27, M29, M32) and six methylisoscutellarein derivatives (M62, M63, M7, M10, M4, M41). In the S. scardica decoction, isoscutellarein was present with seven derivatives: three isoscutellarein and four methylisoscutellarein derivatives. Isoscutellarein derivatives M18 (isoscutellarein sufate), M32 (isoscutellarein glucuronide-sufate), M7 (methylisoscutellarein glucuronide) and M4 (methylisoscutellarein diglucuronide) were the dominant metabolites present in urine samples of all volunteers (Figure 5b).

It is noticeable that hypolaetin and isoscutellarein derivatives were mostly found (almost in all volunteers in all days) in the forms of sulfate (M18) or glucuronide-sulfate (M11, M32), whereas methylhypolaetin and methylisoscutellarein derivatives were mainly in the forms of glucuronides (M56, M57, M7, M4). This is an interesting finding that has to be further studied and compared with analogous flavonoids pairs.

As for the other most abundant group of polyphenols in the $S$. scardica decoction, phenylethanoid glycosides, it was found that they showed very low bioavailability after oral administration of the decoction rich with these compounds. This has also been pointed out previously and has been attributed to their poor absorption in the gastrointestinal tract [18]. In contrast, flavonoid glycosides have shown significant bioavailability, which has been previously also pointed out and attributed to the fact that hypolaetin and isoscutellarein posses hydroxyl groups at specific positions $\left(3^{\prime}\right.$ and $\left.4^{\prime}\right)$ [19].

Acknowledgement. The authors are grateful to Dr. Vassya Bankova and Dr. Kalina Alipieva from the Institute of Organic Chemistry with Centre of Phytochemistry, Bulgarian Academy of Sciences, Sofia, Bulgaria, for providing the reference substances used in this study.

\section{REFERENCES}

[1] E. González-Burgos, M. E. Carretero, M. P. Gómez-Serranillos, Sideritis spp.: Uses, chemical composition and pharmacological activities. A review, J. Ethnopharmacol., 135, 209-225 (2011).

[2] M. I. Gil, F. Ferreres, A. Marrero, F. TomasLorente, F. A. Tomas-Barberan, Distribution of flavonoid aglycones and glycosides in Sideritis species from the Canary Islands and Maderia, Phytochemistry, 34, 227-232 (1993).

[3] F. A. Tomas-Barberan, M. I. Gil, F. Ferreres, D. Rivera, C. Obon, F. Tomas-Lorente, Distribution of 8-hydroxyflavone glycosides and flavonoid aglycones in some Spanish Sideritis species, Biochem. Syst. Ecol., 21, 487-497 (1993).

[4] A. Sattar, V. Bankova, S. Popov, Flavonoid glycosides from Sideritis species, Fitoterapia, 64, 278-279 (1993)

[5] A. Sattar, V. Bankova, S. Popov, Acylated flavonoid glycosides from Sideritis scardica, Fitoterapia, 66, 190 (1995).

[6] J. Petreska, M. Stefova, F. Ferreres, D. A. Moreno, F. A. Tomás-Barberán, G. Stefkov, S. Kulevanova, A. Gil-Izquierdo, Potential bioactive phenolics of Macedonian Sideritis species used for medicinal "Mountain Tea", Food Chem., 125, 13-20 (2011).

[7] J. Petreska, G. Stefkov, S. Kulevanova, K. Alipieva, V. Bankova, M. Stefova, Phenolic compounds of Mountain Tea from the Balkans: LC/DAD/ESI/ $\mathrm{MS}^{n}$ profile and content, Nat. Prod. Commun., 6, 21-30 (2011).

[8] B. M. Fraga, Phytochemistry and chemotaxonomy of Sideritis species from the Mediterranean region, Phytochemistry, 76, 7-24 (2012).

[9] N. Ezer, M. K. Sakar, B. Rodríguez, M. C. De La Torre, Flavonoid glycosides and a phenyl propanoidglycoside from Sideritis perfoliata, Int. J. Pharmacogn, 30, 61-65 (1992).

[10] G. Williamson, C. Manach, Bioavailability and bioefficacy of polyphenols in humans. II. Review of 93 intervention studies, Am. J. Clin. Nutr., 81, 243S255S (2005).

[11] J. Petreska, M. Stefova, F. Ferreres, D. A. Moreno, F. A. Tomás-Barberán, G. Stefkov, S. Kulevanova, A. Gil-Izquierdo, Dietary Burden of Phenolics per Serving of "Mountain Tea" (Sideritis) from Macedonia and Correlation to Antioxidant Activity, Nat. Prod. Commun., 6, 1305-1314 (2011). 
[12] K. Alipieva, J. Petreska, Á. Gil-Izquierdo, M. Stefova, Lj. Evstatieva, V. Bankova, Influence of the extraction method on the yield of flavonoids and phenolics from Sideritis spp. (Pirin Mountain tea), Nat. Prod. Commun., 5, 51-54 (2010).

[13] A. A. Sattar, Flavonoids and Terpenoids in Some Representatives of Lamiaceae Family, Bulgarian Academy of Sciences, Sofia, 1994.

[14] K. D. R. Setchell, A. Cassidy, Dietary Isoavones: Biological Effects and Relevance to Human Health, J. Nutr., 129, 758S-1767S (1999).

[15] D. H. Kim, E. A. Jung, I. S. Sohng, J. A. Han, T. H. Kim, M. J. Han, Intestinal bacterial metabolism of flavonoids and its relation to some biological activities, Arch. Pharm. Res., 21, 17-23 (1998).

[16] J. Winter, L. H. Moore, V. R. Dowell, V. D. Bokkenheuser, C-ring cleavage of flavonoids by human intestinal bacteria, Appl. Environ. Microbiology, 55, 1203-1208 (1989).

[17] A. J. Day, M. S. du Pont, S. Ridley, M. Rhodes, M. J. Rhodes, M. R. Morgan, Deglycosylation of flavonoid and isoflavonoid glycosides by human small intestine and liver $\beta$-glucuronidase activity, FEBS Lett., 436, 71-75 (1998).

[18] C. Jia, H. Shi, W. Jin, K. Zhang, Y. Jiang, M. Zhao, P. Tu, Metabolism of Echinacoside, a Good Antioxidant, in Rats: Isolation and Identification of Its Biliary Metabolites, Drug Metab. Dispos,. 37, 431-438 (2009).

[19] G. Williamson, G. W. Plumb, Y. Uda, K. R. Price, M. J. C. Price, Dietary quercetin glycosides: antioxidant activity and induction of the anticarcinogenic phase II marker enzyme quinone reductase in Hepalc1c7 cells, Carcinogenesis, 17, 2385-2387 (1996). 
